\title{
METHACYCLINE IN NON-GONOCOCCAL URETHRITIS*
}

\author{
BY \\ R. S. MORTON AND PAMELA M. WRAY \\ Royal Hospital, Sheffield
}

Methacycline (6 methylene-5-hydroxytetracycline) is a wide-spectrum antibiotic which belongs to the class of 6 methylenetetracyclines first described by Blackwood, Beereboom, Rennhard, von Wittenhau, and Stephens (1961). It has been reported to be effective against a wide range of organisms ( Te-Wen Chang and Weinstein, 1962; English, McBride, and Riggio, 1962), including the gonococcus (Marmell, Sills, and Prigot, 1962). A dose of $150 \mathrm{mg}$. thought to be the equivalent of $250 \mathrm{mg}$. tetracycline or oxytetracycline induces serum levels of $0 \cdot 39-3 \cdot 12 \mu \mathrm{g} . / \mathrm{ml}$. serum, reaching double these levels in the occasional patient (Limson and Guevara, 1963). Higher levels of plasma binding (in vitro though probably not in vivo) have been described with methacycline than with tetracycline (Remington and Finland, 1962); these writers also reported a higher incidence of side-effects, particularly nausea, vomiting, and diarrhoea, with methacycline than with tetracycline.

Taking these facts into account, it was decided to make use of methacycline in a small series of cases of non-gonococcal urethritis (NGU), though the search for an ideal treatment for NGU is unlikely to be successful until the aetiology is more fully understood.

\section{Patients Studied}

The series consisted of fifty men with non-gonococcal urethritis, the only basis of selection being the probability of return for surveillance. One case of Reiter's disease was included. 37 were born in the United Kingdom, four in Pakistan, three in Jamaica, three in Aden, one in West Africa, one in Somaliland, and one in Italy. The average age was 30 years (range 16-51). Nine of the 29 married men denied an extra-marital risk. A history of urethritis was given in $\mathbf{2 3}$ cases: five had had both gonorrhoea and NGU, six gonorrhoea only, and twelve NGU only. The estimated incubation period ranged from 3 days to 6 months and was thought to be less than 10 days in twelve, more than 10 days in 33, and unknown in five. In five cases the duration of the discharge was longer than 10 days. The discharge was mucoid in five, purulent in twelve, and muco-purulent in 29 , whilst no discharge was detected in four though the

\footnotetext{
* Received for publication February 16, 1966
}

history, leucocytic urethral scrape, and hazy urine bore out the diagnosis. The first urine in the two-glass urine tests was hazy with flocculations or contained flocculations alone in 47 cases, in eight cases the specimen in the second glass also showed a haze of pus, whilst in eleven cases no second glass specimen was passed.

\section{Management}

Gonorrhoea was excluded by Gram-stained smears and by culture, and trichomoniasis either by wet film and methyl violet-stained film or by wet film and culture. Blood was taken for a Wassermann reaction, Kahn test, and Reiter protein complement-fixation test from all patients at their initial visit.

The treatment given was methacycline $150 \mathrm{mg}$. 6-hrly for sixteen doses.

The patients were asked to return for examination on the $3 \mathrm{rd}, 7 \mathrm{th}, 14 \mathrm{th}, 21 \mathrm{st}, 35 \mathrm{th}, 60 \mathrm{th}$, and 90th days. In fact four cases never attended again, five re-attended once only on the 3rd or 4th day, and only 21 for 2 months or longer. Prostatic massage and examination of prostatic fluid was advised between the 2nd and 4th week after treatment and was completed in twenty cases.

\section{Results}

Successful treatment is defined as the absence of urethral discharge and a clear urine. One patient was excluded from the series: he had a recurrence 9 weeks after treatment when a culture of urethral discharge grew Trichomonas vaginalis and further sexual risk was denied. His prostatic fluid was the only one of the twenty examined which contained an excessive number of pus cells. 39 of the remaining 49 patients responded to treatment, giving a success rate of 79.6 per cent.

Four patients did not return after treatment and by definition are not classed as successes.

Two men had slight mucoid urethral discharge and hazy urine on the 3rd and 4th post-treatment day respectively, but did not return and are included with the failures.

The case of Reiter's disease still had a mucopurulent urethral discharge on the 2 nd and 3 rd days of treatment, though the eye and joint manifestations were subsiding. There was no previous history of NGU or Reiter's disease. 
The only other immediate failure still had a mucopurulent urethral discharge on the 4th posttreatment day. He had NGU three times previously and a prostatic bar had been detected on cystoscopic examination.

Two other cases are counted as failures since no note was made of a new exposure to risk: one had a recurrence of signs and symptoms 4 weeks after treatment and one after 6 weeks. Both had had NGU previously.

Four of the successfully-treated cases had recurrences at 13 days, 14 days, 5 weeks, and 10 weeks respectively - all admitted a new risk.

Side-effects of the Drug.-Nausea, vomiting, and diarrhoea were complained of by four men; in no case were the symptoms so distressing that the drug had to be discontinued.

\section{Discussion}

Assessment of treatment schedules in NGU is never easy. The absence of a recognizable cause of the condition, its variable clinical presentation, its recurrent nature, and no less the absence of doubleblind trials all contribute to this. There is little doubt, however, that some antibiotics do favourably modify the disease both strikingly and promptly. It is widely agreed that the tetracycline group falls into this category (Willcox, 1953, 1955; Morton and Read, 1957; Doyle, Gill, and Laird, 1957; Csonka and Rosedale, 1962). In these circumstances we have felt it permissible to dispense with a comparable number of untreated controls.

A response rate of 79.6 per cent. compares well with the response to other antibiotics and is in keeping with those resulting from administration of other members of the tetracycline group.

One of our failures showed the features noted as common in those failing to respond (Csonka and Rosedale, 1962), i.e. previous history of NGU and previous failure to respond to treatment.

Side-effects of methacycline were few, and did not necessitate withdrawal of the antibiotic.

\section{Summary}

(1) Fifty cases of NGU were treated with methacycline $150 \mathrm{mg}$. 6-hrly for 4 days. One case was excluded from the series when Trichomonas vaginalis was found later.

(2) The type of urethritis and duration of discharge are noted.

(3) Successful treatment as defined occurred in 39 (79.6 per cent.).

(4) The results compare favourably with those obtained with other tetracyclines.

We are pleased to acknowledge the help of the clinic staff and the gift of methacycline from Pfizer Limited.

\section{REFERENCES}

Blackwood, R. K., Beereboom, J. J., Rennhard, H. H., Wittenau, M. Schach von, and Stephens, C. R. (1961). J. Amer. chem. Soc., 83, 2773.

Csonka, G. W., and Rosedale, N. (1962). Brit. J. vener. Dis., 38, 157.

Doyle, J. O., Gill, A. J., and Laird, S. M. (1957). Ibid., 33, 100.

English, A. R., McBride, T. J., and Riggio, R. (1962). In "Antimicrobial Agents and Chemotherapy1961", pp. 362-473. American Society for Microbiology, Detroit, Michigan.

Limson, B. M., and Guevara, R. (1963). Curr. ther. Res., $5,249$.

Marmell, M., Sills, J. R., and Prigot, A. (1963). "Antimicrobial Agents and Chemotherapy-1962", p. 502.

Morton, R. S., and Read, L. (1957). Brit. J. vener. Dis., 33, 223.

Remington, J. S., and Finland, M. (1962). Clin. Pharmacol. Ther., 3, 284.

Te-Wen Chang, and Weinstein, L. (1962). Antibiot. and Chemother., 12, 676.

Willcox, R. R. (1953). Brit. J. vener. Dis., 29, 225.

- (1955). Ibid., 31, 89.

\section{Le traitement de l'urétrite non-gonococcique par la méthacycline \\ RÉSUMÉ}

(1) Cinquante cas d'urétrite non-gonococcique ont été traités par la méthacycline à la dose de $150 \mathrm{mg}$. toutes les six heures pendant 4 jours. Un cas a été exclu de la série quand des Trichomonas vaginalis ont été découverts plus tard.

(2) Le genre d'urétrite et la durée de l'écoulement ont été notés.

(3) La cure radicale comme décrite a eu lieu chez 39 malades $(79,6$ pour cent).

(4) Les résultats se comparent favorablement à ceux obtenus avec d'autres tétracyclines. 